\title{
Distinct lonotropic GABA Receptors Mediate Presynaptic and Postsynaptic Inhibition in Retinal Bipolar Cells
}

\author{
Colleen R. Shields, ${ }^{1,3}$ My N. Tran, ${ }^{1}$ Rachel O. L. Wong, ${ }^{2,3}$ and Peter D. Lukasiewicz ${ }^{1,2,3}$ \\ ${ }^{1}$ Department of Ophthalmology and Visual Sciences, ${ }^{2}$ Department of Anatomy and Neurobiology, and ${ }^{3}$ Neuroscience \\ Program, Washington University School of Medicine, St. Louis, Missouri 63110
}

Ionotropic GABA receptors can mediate presynaptic and postsynaptic inhibition. We assessed the contributions of $\mathrm{GABA}_{\mathrm{A}}$ and $\mathrm{GABA}_{C}$ receptors to inhibition at the dendrites and axon terminals of ferret retinal bipolar cells by recording currents evoked by focal application of GABA in the retinal slice. Currents elicited at the dendrites were mediated predominantly by $\mathrm{GABA}_{A}$ receptors, whereas responses evoked at the terminals had $G A B A_{A}$ and $G_{A B A}$ components. The ratio of $G A B A_{C}$ to $G_{A B A}\left(G_{A} A B A_{C}\right.$ : $G A B A_{A}$ ) was highest in rod bipolar cell terminals and variable among cone bipolars, but generally was lower in OFF than in ON classes. Our results also suggest that the $\mathrm{GABA}_{\mathrm{C}}: \mathrm{GABA}_{\mathrm{A}}$ could influence the time course of responses. Currents evoked at the terminals decayed slowly in cell types for which the $G_{A B A_{C}}: G A B A_{A}$ was high, but decayed relatively rapidly in cells for which this ratio was low. Immunohistochemical studies corroborated our physiological results. GABA $_{A} \beta 2 / 3$ subunit immunoreactivity was intense in the outer and inner plexiform layers (OPL and IPL, respectively). GABA $\rho$ subunit labeling was weak in the OPL but strong in the IPL in which puncta colocalized with terminals of rod bipolars immunoreactive for protein kinase $\mathrm{C}$ and of cone bipolars immunoreactive for calbindin or recoverin. These data demonstrate that $\mathrm{GABA}_{\mathrm{A}}$ receptors mediate GABAergic inhibition on bipolar cell dendrites in the OPL, that $\mathrm{GABA}_{A}$ and $\mathrm{GABA}_{C}$ receptors mediate inhibition on axon terminals in the IPL, and that the GABA ${ }_{C}$ : $\mathrm{GABA}_{\mathrm{A}}$ on the terminals may tune the response characteristics of the bipolar cell.

Key words: GABA; ionotropic GABA receptors; $G A B A_{A}$ receptors; $G A B A_{C}$ receptors; retinal bipolar cells; cone bipolar cells; rod bipolar cells; presynaptic inhibition; postsynaptic inhibition
Throughout the CNS, GABA is an abundant and important inhibitory neurotransmitter. There are two distinct ionotropic GABA receptors, $\mathrm{GABA}_{\mathrm{A}}$ and $\mathrm{GABA}_{\mathrm{C}}$, which are physiologically, pharmacologically, and molecularly distinct (for review, see Bormann and Feigenspan, 1995; Lukasiewicz, 1996; Hevers and Lüddens, 1998). For example, GABA elicits currents that decay more slowly when mediated by $\mathrm{GABA}_{\mathrm{C}}$ receptors than by $\mathrm{GABA}_{\mathrm{A}}$ receptors (Qian and Dowling, 1993, 1995; Amin and Weiss, 1994; Lukasiewicz and Wong, 1997; Lukasiewicz and Shields, 1998a), and the affinity for GABA is greater at $\mathrm{GABA}_{\mathrm{C}}$ receptors than at $\mathrm{GABA}_{\mathrm{A}}$ receptors (Amin and Weiss, 1994; Feigenspan and Bormann, 1994). Understanding how GABA modulates neuronal excitation thus requires knowledge of how $\mathrm{GABA}_{\mathrm{A}}$ and $\mathrm{GABA}_{\mathrm{C}}$ receptors contribute to the overall GABAergic response of the neuron.

In the retina, in which there is an abundance of $\mathrm{GABA}_{\mathrm{A}}$ and $\mathrm{GABA}_{\mathrm{C}}$ receptors, there are distinct patterns of expression for these two receptor subtypes (for review, see Lukasiewicz and Shields, 1998b). Retinal neurons that possess both $\mathrm{GABA}_{\mathrm{A}}$ and $\mathrm{GABA}_{C}$ receptors are thus good models for understanding how spatial localization of distinct receptors and their relative expres-

Received Oct. 8, 1999; revised Jan. 10, 2000; accepted Jan. 21, 2000.

This work was supported by National Institutes of Health Grants EY08922 (P.D.L.), EY07057 (C.R.S.), EY10699 (R.O.L.W.), and EY02687 (Department of Ophthalmology), and Research to Prevent Blindness. We thank Dr. Paul B. Cook, Dr. Carl Romano, and Matt Higgs for their insightf ul comments on this manuscript.

Correspondence should be addressed to Dr. Peter D. Lukasiewicz, Department of Ophthalmology and Visual Sciences, Campus Box 8096, Washington University School of Medicine, St. Louis, MO 63110-1093. E-mail: lukasiewicz@vision. wustl.edu.

Copyright (C) 2000 Society for Neuroscience $\quad 0270-6474 / 00 / 202673-10 \$ 15.00 / 0$ sion can shape synaptic responses. One such cell is the retinal bipolar cell, which has dendrites located in the outer plexiform layer (OPL) in which inhibition affects responses to photoreceptor input, and axon terminals located in the inner plexiform layer (IPL) in which inhibition modulates transmission from bipolar cells to ganglion cells. Although these cells have been demonstrated by both electrophysiology and immunocytochemistry to have $\mathrm{GABA}_{\mathrm{A}}$ and $\mathrm{GABA}_{\mathrm{C}}$ receptors, it is not yet fully understood how each receptor subtype contributes to inhibition at the dendrites and axon terminals of the cell.

To examine the contributions of $\mathrm{GABA}_{\mathrm{A}}$ and $\mathrm{GABA}_{\mathrm{C}}$ receptors to inhibition at the dendritic and axon arbors of bipolar cells, it is necessary to selectively activate GABA receptors in the OPL or IPL. In this study, bipolar cell responses to GABA were examined under whole-cell voltage clamp in slices of mature ferret retina using a brief, focal application of GABA (puff) at the OPL or IPL. The contribution of each receptor subtype to these currents was determined pharmacologically, and the time courses of the evoked responses were measured. We also compared the physiological ratio of $\mathrm{GABA}_{\mathrm{A}}$ and $\mathrm{GABA}_{\mathrm{C}}$ receptors on the terminals of different bipolar cell classes and examined the patterns of immunolabeling for these two receptors, because differences in their relative expression may allow functionally distinct cell classes to generate diverse inhibitory responses.

\section{MATERIALS AND METHODS}

Preparation of ferret retinal slices. Ferrets (postnatal day 28 to adult) were obtained from Marshall Farms (North Rose, NY). Housing, care, and use of ferrets are in accordance with the Washington University Animal Studies Committee and National Institutes of Health guidelines. Animals were deeply anesthetized with 4-5\% halothane (Halocarbon Laborato- 
ries, River Edge, NJ), eyes were enucleated, and animals were killed with an overdose of halothane or with an intracardiac (or intraperitoneal) injection of sodium pentobarbital (The Butler Company, Columbus, $\mathrm{OH}$ ).

Immediately after enucleation, the anterior portion of the eye (lens and cornea) and vitreous were removed. Retinae were dissected in cold, oxygenated extracellular medium (see Electrode and bath solutions) buffered with $20 \mathrm{~mm}$ HEPES to $\mathrm{pH} 7.4$ and maintained in this medium at room temperature. Slices were prepared as described previously (Lukasiewicz and Wong, 1997).

Whole-cell patch recordings. Whole-cell patch recordings (Hamill et al., 1981) were obtained from rod and cone bipolar cells in ferret retinal slices. The microscope system and recording procedures have been described in detail previously (Lukasiewicz and Roeder, 1995). Electrodes were pulled from borosilicate glass (TW150F-4; World Precision Instruments, Sarasota, FL) with a Sachs-Flaming puller (Sutter Instruments, Novato, CA) and had measured resistances of $<5 \mathrm{M} \Omega$. Patchit software (White Perch Software, Somerville, MA) was used to generate voltage command outputs, acquire data, gate the drug perfusion valves, and trigger the Picospritzer (General Valve, Fairfield, NJ). The data were digitized and stored with a 486 personal computer using a Labmaster DMA data acquisition board (Scientific Solutions, Solon, OH). Responses were filtered at $1 \mathrm{kHz}$ with the four-pole Bessel low-pass filter on the Axopatch 200B (Axon Instruments, Foster City, CA) and sampled at $0.3-2 \mathrm{kHz}$.

Data analysis. Tack software (White Perch Software) was used to average records and to determine the charge transfer. Leak-subtracted responses $(n=2-4)$ were averaged to obtain the current traces depicted in the figures. The decay of the current was not easily fit by exponentials. Thus, the decay was measured from peak to $37 \%$ of peak current amplitude $\left(D_{37}\right)$. Sigma Plot software (SPSS, Chicago, IL) was used to calculate the $D_{37}$ and to determine the time from the GABA puff to peak current amplitude. Data in text and figure legends are expressed as mean \pm SE. Levels of significance were determined using the Student's $t$ test.

Electrode and bath solutions. The standard bathing medium [normal ferret ringer (NFR)] contained (in $\mathrm{mM}$ ) 128 sodium chloride, 1 magnesium chloride, 5 potassium chloride, 2 calcium chloride, 10 glucose, and 20 HEPES. The standard intracellular electrode solution for puff experiments consisted of (in mM) 118 cesium chloride, 10 tetraethylammonium chloride (TEA), 0.4 magnesium chloride, 1 EGTA, and 10 sodium HEPES, adjusted to $\mathrm{pH} 7.3$ with hydrochloric acid. Synaptic responses were recorded using a low-chloride electrode solution containing cesium gluconate $(118 \mathrm{~mm})$ in place of cesium chloride. Cesium and TEA were included in recording electrodes to block voltage-gated potassium channels (Lukasiewicz and Werblin, 1988). In some experiments, slight variations of the above electrode and bath solutions were used or the bathing solution was Ames medium (Ames and Nesbett, 1981). For experiments using Ames medium, the intracellular electrode solution differed from the standard in cesium concentration and contained (in mM) 105.3 cesium chloride or cesium gluconate. No differences were found between solutions. Unless otherwise indicated, all chemicals were obtained from Sigma (St. Louis, MO).

In NFR bathing solution, the calculated $E_{\mathrm{Cl}}$ was $-2 \mathrm{mV}$ (cesium chloride electrodes) or $-58.5 \mathrm{mV}$ (cesium gluconate electrodes). For experiments in which Ames medium was substituted for NFR, $E_{\mathrm{Cl}}$ was $-2 \mathrm{mV}$ (cesium chloride electrodes) or $-65 \mathrm{mV}$ (cesium gluconate electrodes). Membrane potential values given in this paper were corrected for junction potentials. Liquid junction potentials were calculated using Junction Potential Calculator (Cell MicroControls, Virginia Beach, VA) and were typically -5.2 and $-14.5 \mathrm{mV}$ in NFR for cesium chloride and cesium gluconate electrodes, respectively. When Ames medium was substituted for NFR, the liquid junction potentials were $-3.5 \mathrm{mV}$ (cesium chloride electrodes) and $-13.5 \mathrm{mV}$ (cesium gluconate electrodes).

The control bathing solution used in these slice experiments was formulated to pharmacologically isolate bipolar cell responses to GABA. In all experiments, glycine receptors were antagonized with strychnine (2 $\mu \mathrm{M})$ (Belgum et al., 1984). For GABA puff experiments, AMPA/kainate (AMPA/KA) receptors were blocked with 6-cyano-7-nitroquinoxaline2,3-dione (10 $\mu \mathrm{M})(\mathrm{CNQX})$ [Research Biochemicals (RBI), Natick, MA] (Mittman et al., 1990). GABA A $_{\mathrm{A}}$ receptors were antagonized with bicuculline methbromide $(200 \mu \mathrm{M} ; \mathrm{RBI})$, and $\mathrm{GABA}_{\mathrm{C}}$ receptors were blocked with 3-aminopropyl [methyl]-phosphinic acid (500 $\mu \mathrm{M})$ (3-APMPA) (RBI or Precision Biochemicals, Inc., Vancouver, British Columbia, Canada) (Woodward et al., 1993; Pan and Lipton, 1995). Picrotoxin could not be used to selectively block $\mathrm{GABA}_{\mathrm{A}}$ receptors, because it is an antagonist at both $\mathrm{GABA}_{\mathrm{A}}$ and $\mathrm{GABA}_{\mathrm{C}}$ receptors in the ferret (Lukasiewicz and Wong, 1997). Antagonists were applied to a region of the slice under study (several millimeters in width) by a gravity-driven superfusion system as described previously (Lukasiewicz and Roeder, 1995).

Puffing agonist onto bipolar cell terminals or dendrites. GABA $(200 \mu \mathrm{M})$ was puffed onto either the terminals or dendrites of bipolar cells in the slice preparation with a Picospritzer at 45 or $60 \mathrm{sec}$ intervals. The puff pressure and/or duration (typically $10-30 \mathrm{msec}$ ) were adjusted to give no larger than a half-maximal response. The pipette was positioned to give the fastest possible response rise time. The location of the puff pipette in relation to the terminals or dendrites could be determined with Lucifer yellow included in the recording pipette. Because the slice was continuously superfused (diluting the puff) and puff duration and pressure were submaximal, the GABA concentration at the receptors was most likely much less than the pipette concentration. For most experiments in which GABA was puffed onto the terminals, the direction of superfusion flow was from photoreceptors to ganglion cells to prevent activation of dendritic GABA receptors by diffusion of the GABA puff. For experiments in which slices were in the opposite orientation, the puff pressure, duration, and position could be adjusted to focally activate GABA receptors. Cells were rejected when there was evidence of a double peak in the response, which indicated the activation of receptors on both the dendrites and axon terminals.

Evoking GABAergic IPSCs. GABAergic IPSCs were evoked in bipolar cells by puffing kainate $(250$ or $500 \mu \mathrm{M})$ in the IPL to depolarize amacrine cell processes. GABA receptors were pharmacologically isolated as described above by including strychnine $(2 \mu \mathrm{M})$ in the bathing medium. IPSCs were recorded using cesium gluconate electrodes, and bipolar cells were voltage clamped to $0 \mathrm{mV}$, the reversal potential for nonspecific cation currents.

Identification and classification of bipolar cells. Bipolar cell class was determined with Lucifer yellow (0.015-0.02\%) included in the recording electrode. Bipolar cells were documented by photographing and/or drawing by hand at the conclusion of each experiment. Rod bipolar cells (see Fig. $2 A$, cells 1,2 ) stratified close to the border of the inner plexiform and ganglion cell layers and had the morphology described for rat rod bipolar cells (Euler and Wässle, 1995). ON cone bipolar cells (see Fig. $2 A$, cells $3,4)$ stratified in the proximal two-thirds of the IPL, and OFF cone bipolar cells (see Fig. $2 A$, cells 5-7) stratified in the distal one-third of the IPL, similar to the ON and OFF sublaminae in the cat IPL (Famiglietti and Kolb, 1976; Nelson et al., 1978; Peichl and Wässle, 1981).

Immunolabeling. Eyecups were prepared as described above and fixed by immersion in $4 \%$ paraformaldehyde in $0.1 \mathrm{M}$ phosphate buffer, $\mathrm{pH} 7.4$, for 25-30 min. The paraformaldehyde-fixed eyecups were rinsed (three times for $10 \mathrm{~min}$ each) in $0.1 \mathrm{M}$ phosphate buffer, and the retinae were isolated carefully. The retinae were placed in warmed $\left(37^{\circ} \mathrm{C}\right) 4 \%$ agarose for $30 \mathrm{~min}$ and then in $4 \%$ agar, which was then allowed to solidify. Vibratome sections $(50 \mu \mathrm{M})$ were cut, washed $(10 \mathrm{~min})$ in a solution of $0.01 \mathrm{M}$ PBS (145 mM NaCl, pH 7.35) and 0.5\% Triton X-100 (T-X), and then incubated at room temperature for $1 \mathrm{hr}$ in a blocking solution consisting of $10 \%$ normal goat serum (NGS) (Vector Laboratories, Burlingame, CA) and $0.5 \% \mathrm{~T}-\mathrm{X}$ in $0.01 \mathrm{M}$ PBS. Sections were incubated overnight at room temperature in the following primary antibodies made up in the blocking solution at the specified dilutions: PKC [1:1000 (rabbit polyclonal antibody to $\alpha, \beta$, and $\gamma$ isozymes; Chemicon, Temecula, CA)], calbindin [1:1000 (mouse monoclonal anti-calbindin-D; Sigma)], recoverin [1:300 (rabbit polyclonal; gift of A. Dizhoor, Kresge Eye Institute, Wayne State University, Detroit, MI)], GABA $\mathrm{A}$ [1:10 (mouse monoclonal antibody to $\beta 2 / 3$ (clone bd 17) subunit of the receptor; Boehringer Mannheim, Indianapolis, IN)], and $\mathrm{GABA}_{\mathrm{C}}$ [1:100 (rabbit polyclonal antibody to $\rho_{1}, \rho_{2}$, and, $\rho_{3}$ subunits of the receptor; gift of Ralf Enz, Johns Hopkins University, Baltimore, MD)]. As a control, the primary antibodies were omitted from one section on each slide.

Before applying secondary antibodies, the sections were rinsed for $1 \mathrm{hr}$ at room temperature with $0.5 \% \mathrm{~T}-\mathrm{X}-0.01 \mathrm{~m}$ PBS. Nonspecific labeling was reduced by incubating the sections in a blocking solution consisting of $3 \%$ NGS and $0.5 \% \mathrm{~T}-\mathrm{X}-0.01 \mathrm{M}$ PBS. Immunofluorescent secondary antibodies Cy-2 (1:1000) or Cy-3 (1:1000) were diluted with the blocking solution and applied for $1 \mathrm{hr}$ at room temperature. The sections were rinsed three times for 5-15 min with PBS and then were mounted in Immumount (Shandon Lipshaw, Pittsburgh, PA).

The protocols for triple and double labeling are similar (see above for details). Sections were first double labeled by incubating overnight in blocking solution (10\% NGS-0.5\% T-X-0.01 M PBS) containing two 
different primary antibodies from two species. The following day, sections were treated as described above, and the appropriate immunofluorescent secondary antibodies diluted in $3 \%$ NGS and $0.5 \% \mathrm{~T}-\mathrm{X}-0.01 \mathrm{M}$ PBS were applied for $1 \mathrm{hr}$. After thorough washing in PBS, sections were incubated overnight in blocking solution containing the third primary antibody. After incubation, sections were treated as described above, and the final secondary antibody was applied for $1 \mathrm{hr}$. After rinsing, sections were mounted in Immumount. We were unable to use this protocol with the $\beta 2 / 3$ and calbindin mouse monoclonal antibodies because of interactions between the final secondary antibody and the first primary antibody (either anti- $\beta 2 / 3$ or anti-calbindin). Another anti-calbindin antibody (anti-rabbit; Swant, Bellinzona, Switzerland) did not produce specific labeling of this population of ON bipolar cells.

Confocal imaging and image analysis. Confocal images were acquired using the Bio-Rad (Hercules, CA) 1024M microscope (krypton-argon laser). Images were captured using a $40 \times$ water or $60 \times$ oil objective (NA 1.4; Olympus Optical, Tokyo, Japan) at a $x-y$ resolution of $512 \times$ 512 or $728 \times 512$ pixels and a z-step appropriate for the magnification of the objective and zoom (typically ranging from $0.1-0.3 \mu \mathrm{m})$. Confocal stacks were analyzed using the Metamorph three-dimensional (3-D) analysis package (Universal Imaging Corp., West Chester, PA). Details of how each image in Results was obtained are given in the text and figure legends.

\section{RESULTS}

\section{$\mathrm{GABA}_{\mathrm{A}}$ receptors predominate on the dendrites of bipolar cells}

In the OPL, inhibition onto bipolar cell dendrites from GABAergic interneurons may modulate bipolar cell responses to photoreceptor input (Fisher and Boycott, 1974; Kolb and West, 1977; Chun and Wässle, 1989; Pourcho and Owczarzak, 1989). Because GABA receptor subtype influences the characteristics of inhibitory currents, we examined the types of ionotropic GABA receptors expressed on the dendrites of bipolar cells in the ferret retinal slice.

Currents were evoked by puffing GABA directly onto bipolar cell dendrites in the OPL after blocking glycine and AMPA/KA receptors (see Materials and Methods). The GABA receptor types mediating these responses were determined pharmacologically by selectively blocking with the $\mathrm{GABA}_{\mathrm{A}}$ receptor antagonist bicuculline or with bicuculline plus the $\mathrm{GABA}_{\mathrm{C}}$ antagonist 3-APMPA. Figure $1 A$ shows currents evoked by puffing GABA onto the dendrites of an OFF cone bipolar cell. The response reached peak amplitude in $128 \mathrm{msec}$ and decayed to $37 \%$ of peak current amplitude $\left(D_{37}\right)$ in $226 \mathrm{msec}$. In a population of bipolar cells, the average $D_{37}$ and time-to-peak were $244 \pm 24 \mathrm{msec}$ $(n=16)$ and $100 \pm 13 \mathrm{msec}(n=16)$, respectively (see Fig. $3 B, C)$. Bicuculline effectively blocked the GABA-evoked current depicted in Figure $1 A$, reducing the charge transfer (measured by integrating the area under the current trace, see Materials and Methods) to $18 \%$ of control levels, and 3-APMPA abolished the small bicuculline-resistant component. Figure $1 B$ illustrates that similar results were observed across a population of bipolar cells, consisting of rod, ON cone, and OFF cone bipolar cell classes. No differences between these bipolar cell types were found. These results suggest that $\mathrm{GABAergic}$ inhibition with a large $\mathrm{GABA}_{\mathrm{A}}$ component and a much smaller $\mathrm{GABA}_{\mathrm{C}}$ component may modulate bipolar cell responses to photoreceptor input.

\section{The time course of GABA-evoked currents at axon terminals varies with bipolar cell class}

Mammalian bipolar cell axon terminals in the IPL express both $\mathrm{GABA}_{\mathrm{A}}$ and $\mathrm{GABA}_{\mathrm{C}}$ receptors and receive input from GABAergic amacrine cells (Chun and Wässle, 1989; Pourcho and Owczarzak, 1989; Feigenspan et al., 1993; Lukasiewicz and Wong, 1997). Currents mediated by $\mathrm{GABA}_{\mathrm{C}}$ receptors decay
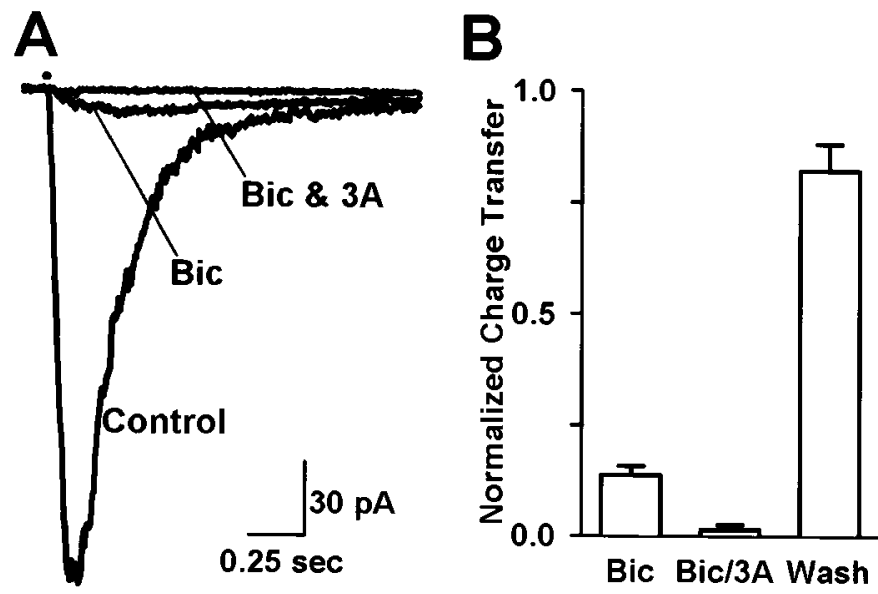

Figure 1. $\mathrm{GABA}_{\mathrm{A}}$ receptors predominate on bipolar cell dendrites. $A$, Current responses evoked by puffing GABA (200 $\mu \mathrm{M}$ pipette concentration) onto bipolar cell dendrites. Horizontal bar above the current traces denotes the duration of the puff in this and all subsequent figures. The control current had a time-to-peak of $128 \mathrm{msec}$ and a $\mathrm{D}_{37}$ of $226 \mathrm{msec}$. Bicuculline $(200 \mu \mathrm{M})$ reduced the response charge transfer to $18 \%$ of control (Bic). 3-APMPA $(300 \mu \mathrm{M})$ decreased the bicuculline-resistant component to $2 \%$ of control (Bic \& $3 A$ ). B, Effects of bicuculline and 3-APMPA on a mixed population of bipolar cells. On average, bicuculline (Bic) reduced the charge transfer to $14 \pm 2 \%(n=15)$ of control. The bicuculline-resistant component was reduced to $2.3 \pm 0.8 \%$ of control by the subsequent addition of 3-APMPA $(B i c / 3 A ; n=12)$. Currents recovered to $82 \pm 6 \%$ of control levels upon washout of antagonist (Wash; $n=15)$.

slowly compared with responses mediated by $\mathrm{GABA}_{\mathrm{A}}$ receptors; however, it is unknown how each receptor subtype contributes to the overall time course of the GABAergic response of a bipolar cell. Therefore, we examined the characteristics of currents evoked by puffing GABA onto the axon terminals of rod, ON cone, and OFF cone bipolar cells. Typical examples of these cell types are illustrated in Figure $2 \mathrm{~A}$.

We found that distinct bipolar cell classes exhibited variations in the time course of GABA-elicited currents. The current traces in Figure $2 B$ illustrate the marked difference in the time courses of GABA-evoked currents in an OFF cone and a rod bipolar cell. The response of the OFF bipolar cell reached peak amplitude in $71 \mathrm{msec}$ and decayed to $37 \%$ of peak amplitude in $284 \mathrm{msec}$. The time-to-peak and $D_{37}$ of the rod bipolar cell response were 213 and $1044 \mathrm{msec}$, respectively. The average $D_{37}$ and time-to-peak data for three populations of bipolar cells are summarized in the bar graph in Figure $2 B$. These data show a general trend for GABA-evoked currents to decay slowly in rod, somewhat faster in ON cone, and most rapidly in OFF cone bipolar cells, but do not reveal differences among these bipolar cells in the time required to reach peak current amplitude.

Consistent with previous studies in expression systems, isolated rod bipolar cells, and retinal slices, our current findings demonstrated that the kinetics of $\mathrm{GABA}_{\mathrm{A}}$ receptor-mediated responses were much faster than those of $\mathrm{GABA}_{\mathrm{C}}$ receptor-mediated currents (Qian and Dowling, 1993, 1995; Amin and Weiss, 1994; Lukasiewicz and Wong, 1997; Lukasiewicz and Shields, 1998a). We recorded responses evoked by puffing GABA onto the axon terminals in the presence of either the $\mathrm{GABA}_{\mathrm{A}}$ antagonist bicuculline or the $\mathrm{GABA}_{\mathrm{C}}$ antagonist 3-APMPA. Figure $3 A$ shows pharmacologically isolated $\mathrm{GABA}_{\mathrm{A}}$ and $\mathrm{GABA}_{\mathrm{C}}$ receptormediated currents recorded from a rod bipolar cell. For comparison, the $\mathrm{GABA}_{\mathrm{A}}$ response is scaled to the amplitude of the 


\section{A}

Figure 2. Time course of GABAergic currents varies among distinct classes of bipolar cells. $A$, Line drawings from photomicrographs of cells included in the recorded rod $(1,2)$, ON cone $(3,4)$, and OFF cone $(5-7)$ bipolar cell populations. Scale bar, $20 \mu \mathrm{m}$. $B$, Currents evoked by puffing GABA $(200 \mu \mathrm{M}$ pipette concentration) onto the terminals of an OFF cone and a rod bipolar cell. The current recorded from the OFF cone bipolar had a $D_{37}$ of $284 \mathrm{msec}$ and a time-to-peak of $71 \mathrm{msec}$ (thick trace, OFF). The $D_{37}$ and time-to-peak of the response measured in the rod bipolar were 1044 and $213 \mathrm{msec}$, respectively (thin trace, Rod). $C$, Average $D_{37}$ and time-to-peak data for populations of rod, ON cone, and OFF cone bipolar cells. The average $D_{37}$ values (white bars) were $808 \pm 92$ $\operatorname{msec}(n=18)$ for rod $(R o d), 638 \pm 77 \mathrm{msec}$ $(n=18)$ for ON cone $(O N)$, and $434 \pm 44$ $\operatorname{msec}(n=18)$ for OFF cone $(O F F)$ bipolar cells. There was a significant difference in the average $D_{37}$ between OFF and ON cone bipolars $(p=0.01)$ and between OFF and rod bipolars $(p<0.001)$, but not between $\mathrm{ON}$ cone and rod bipolar cells $(p=0.08)$. The average time-to-peak values (black bars) were $168 \pm 20 \mathrm{msec}(n=18 ; R o d), 202 \pm 25$ $\operatorname{msec}(n=18 ; O N)$, and $150 \pm 20 \operatorname{msec}(n=$ $18 ; O F F)$. No significant differences in the time-to-peak were found between classes of bipolar cells.
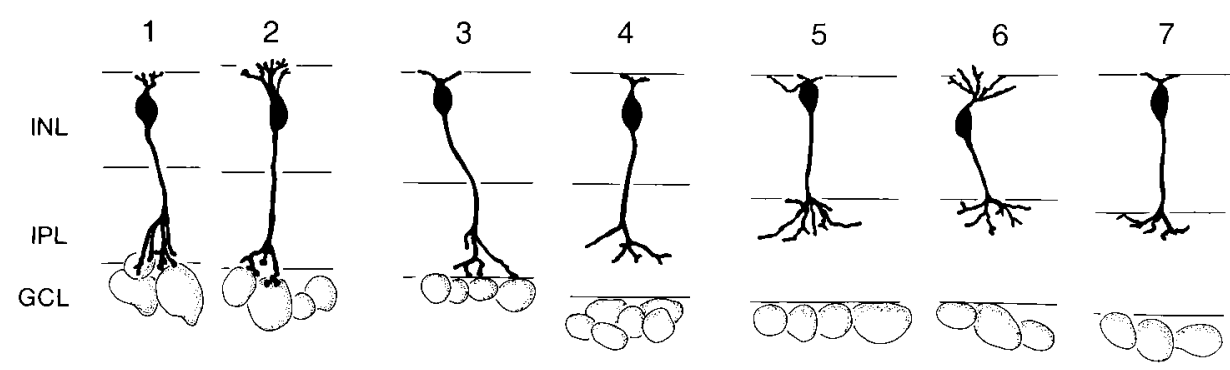

B
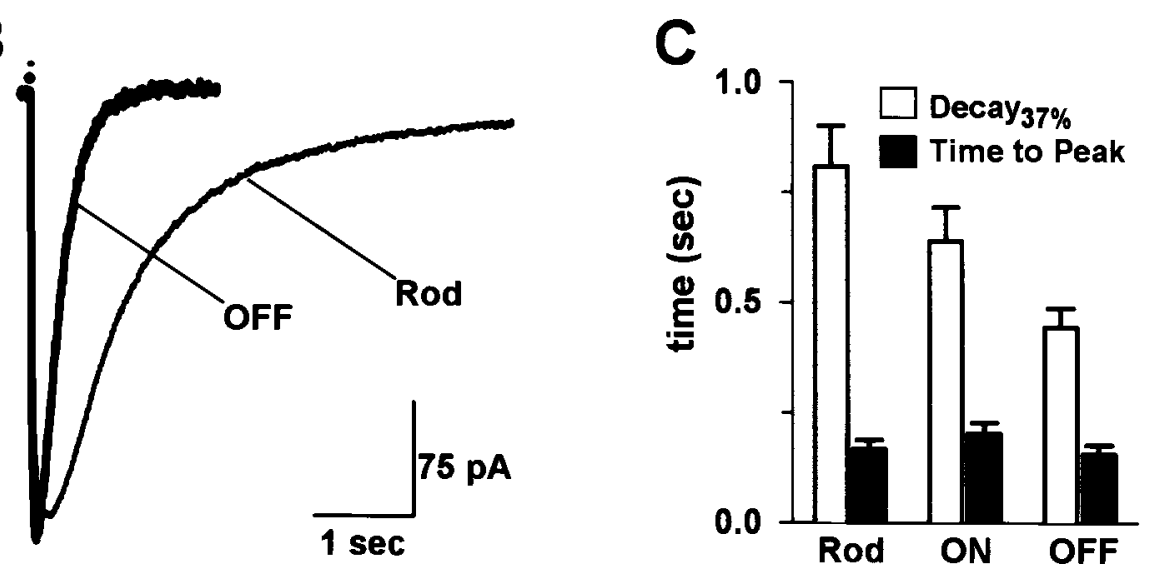

$\mathrm{GABA}_{\mathrm{C}}$ response. The $\mathrm{GABA}_{\mathrm{A}}$ receptor-mediated current reached its peak amplitude in $58 \mathrm{msec}$ and had a $D_{37}$ of $112 \mathrm{msec}$, whereas the $\mathrm{GABA}_{\mathrm{C}}$ component reached peak amplitude in 170 msec and had a $D_{37}$ of $1037 \mathrm{msec}$. Figure $3, B$ and $C$, shows that, across all classes of bipolar cells, the average $D_{37}$ and time-topeak for responses evoked at the terminals were significantly faster for $\mathrm{GABA}_{\mathrm{A}}$ than for $\mathrm{GABA}_{\mathrm{C}}$ receptors. Note that the average $D_{37}$ and time-to-peak of currents mediated by $\mathrm{GABA}_{\mathrm{A}}$ receptors on the terminals were similar to those of responses evoked at the dendrites in which $\mathrm{GABA}_{\mathrm{A}}$ receptors predominate. Likewise, neither the peak amplitude nor the total charge transfer were significantly different between $\mathrm{GABA}_{\mathrm{A}}$ receptor-mediated currents elicited at the terminals and total currents evoked at the dendrites. In contrast, the peak amplitude was similar $(p=0.26)$ and the total charge transfer was greater $(p<0.001)$ in total currents evoked at the axon terminals compared with total responses elicited at the dendrites. This result is consistent with the idea that $\mathrm{GABA}_{\mathrm{C}}$ receptors are abundant at bipolar cell axon terminals but primarily absent from the dendrites.

\section{The relative expression of $\mathrm{GABA}_{\mathrm{A}}$ and $\mathrm{GABA} C$} receptors varies with bipolar cell class

Because of the distinct kinetics of $\mathrm{GABA}_{\mathrm{A}}$ and $\mathrm{GABA}_{\mathrm{C}}$ receptors, their relative expression on bipolar cell terminals could underlie differences in the time course of GABAergic inhibition between cell classes. To determine whether the relative expression of $\mathrm{GABA}_{\mathrm{A}}$ and $\mathrm{GABA}_{\mathrm{C}}$ receptors on bipolar cell terminals could account for the differences in response time course, we recorded GABA-evoked currents in the presence and absence of specific GABA receptor antagonists.
Our pharmacological studies revealed differences among rod, ON cone, and OFF cone bipolar cells in the proportion of $\mathrm{GABA}_{\mathrm{A}}$ and $\mathrm{GABA}_{\mathrm{C}}$ receptors present on axon terminals. The current traces in Figure 4 were recorded from a rod, an ON cone, and an OFF cone bipolar cell. Bicuculline and 3-APMPA differed in their ability to antagonize GABA-evoked currents in these three morphologically distinct bipolar cells. As shown in Figure 4A-C (left column, Bicuculline), the $\mathrm{GABA}_{\mathrm{A}}$ antagonist bicuculline reduced GABA-evoked currents most effectively in the OFF cone, less in the ON cone, and least in the rod bipolar cell. The $\mathrm{GABA}_{\mathrm{C}}$ antagonist 3-APMPA (right column, 3-APMPA), however, was most effective in the rod bipolar cell and least effective in the OFF cone bipolar cell.

Figure $5 A$ shows that bicuculline most effectively reduced the charge transfer of GABA-elicited responses in OFF cone bipolar cells, but was less effective in $\mathrm{ON}$ cone and least effective in rod bipolar cells. In contrast, Figure $5 B$ shows that the effects of 3-APMPA were smallest in OFF cone, greater in ON cone, and greatest in rod bipolar cells. These results suggest that the ratio of $\mathrm{GABA}_{\mathrm{C}}$ to $\mathrm{GABA}_{\mathrm{A}}$ receptors expressed on axon terminals varies among cell types. The $\mathrm{GABA}_{\mathrm{C}}$ component was highest in rod bipolar cells, generally intermediate in $\mathrm{ON}$ cone bipolar cells, and lowest in OFF cone bipolar cells. Within the ON and OFF cone bipolar cell populations, however, there are exceptions to this trend that were not readily apparent in the population data.

As shown in Figures 2 and 3, OFF cone bipolar cell responses were very brief compared with those of rod and ON cone bipolar cells, and currents mediated by $\mathrm{GABA}_{\mathrm{A}}$ receptors were very transient compared with those mediated by $\mathrm{GABA}_{\mathrm{C}}$ receptors. 


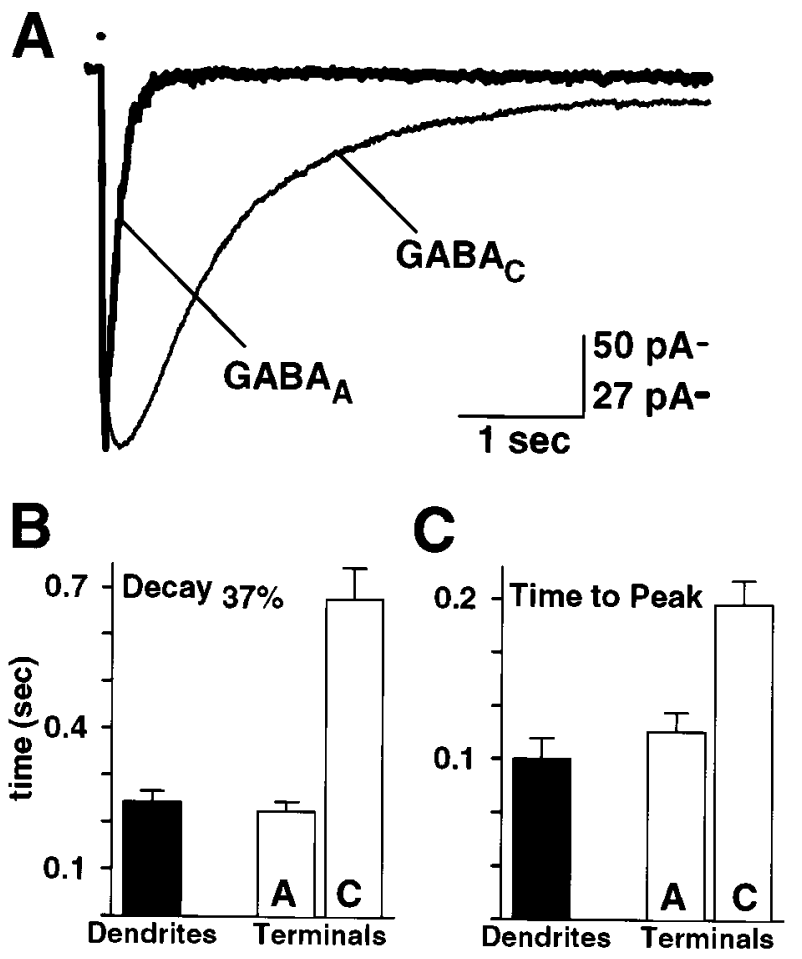

Figure 3. $\mathrm{GABA}_{\mathrm{A}}$ and $\mathrm{GABA}_{\mathrm{C}}$ receptor-mediated currents have distinct time courses. $A$, Current responses evoked by puffing GABA $(200 \mu \mathrm{M}$ pipette concentration) onto the axon terminals of a single rod bipolar cell in the presence of either bicuculline $(200 \mu \mathrm{M})$ (thin trace, $\left.G A B A_{C}\right)$ or 3-APMPA $(300 \mu \mathrm{M})$ (thick trace, $\left.G A B A_{A}\right)$. For comparison, the trace marked $G A B A_{A}$ has been scaled to the amplitude of the trace marked $G A B A_{C}$. Vertical calibration bar: $\mathrm{GABA}_{\mathrm{C}}, 50 \mathrm{pA} ; \mathrm{GABA}_{\mathrm{A}}, 27 \mathrm{pA}$. In the presence of 3-APMPA, the GABA A $_{\text {A }}$ receptor-mediated current had a $D_{37}$ of $112 \mathrm{msec}$ and a time-to-peak of $58 \mathrm{msec}$. The $\mathrm{GABA}_{\mathrm{C}}$ component, recorded in the presence of bicuculline, had a $D_{37}$ of $1037 \mathrm{msec}$ and a time-to-peak of $170 \mathrm{msec} . B$, $C$, Time course data for currents evoked at the dendrites or axon terminals in a mixed population of bipolar cells. $B$, The average $D_{37}$ of currents evoked at the dendrites (black bar) was $244 \pm$ $24 \mathrm{msec}(n=16)$. For responses evoked at the terminals (white bars), the average $D_{37}$ of currents mediated by GABA receptors (labeled $A$ ) was $225 \pm 20 \mathrm{msec}(n=36)$ and by $\mathrm{GABA}_{\mathrm{C}}$ receptors (labeled $\left.C\right)$ was $677 \pm$ $66 \mathrm{msec}(n=40)$. The average $D_{37}$ of $\mathrm{GABA}_{\mathrm{A}}$ receptors on the axon terminals was significantly different from $\mathrm{GABA}_{\mathrm{C}}$ receptors on the terminals $(p<0.001)$, but not from GABA receptors on the dendrites $(p=$ 0.3). $C$, Currents evoked at the dendrites (black bar) reached peak amplitude in an average of $100 \pm 13 \mathrm{msec}(n=16)$. For currents evoked at the axon terminals (white bars), the average time-to-peak of the $\mathrm{GABA}_{\mathrm{A}}$ component (labeled $\left.A\right)$ was $120 \pm 12 \mathrm{msec}(n=36)$ and of the $\mathrm{GABA}_{\mathrm{C}}$ component (labeled $C$ ) was $192 \pm 15 \mathrm{msec}(n=40)$. The average time-to-peak of $\mathrm{GABA}_{\mathrm{A}}$ receptors on the terminals was significantly different from $\mathrm{GABA}_{\mathrm{C}}$ receptors on the terminals $(p<0.001)$, but not from dendritic GABA receptors $(p=0.1)$.

Together with the finding that the relative expression of $\mathrm{GABA}_{\mathrm{A}}$ and $\mathrm{GABA}_{\mathrm{C}}$ receptors on axon terminals varies with cell class, our time course data suggest that the relative expression of GABA receptor subtypes may influence response kinetics. That is, currents in cells with a high $\mathrm{GABA}_{\mathrm{C}}$ to $\mathrm{GABA}_{\mathrm{A}}$ ratio are longer lasting relative to currents in cells with a lower $\mathrm{GABA}_{\mathrm{C}}$ to $\mathrm{GABA}_{\mathrm{A}}$ ratio. Although there is a possibility for additional contributions from other factors, such as differences in GABA uptake mechanisms, receptor subunit composition, and barriers to diffusion, our data support a role for the relative expression of $\mathrm{GABA}_{\mathrm{A}}$ and $\mathrm{GABA}_{\mathrm{C}}$ receptors in determining the time course of GABAergic inhibition in mammalian retinal neurons.
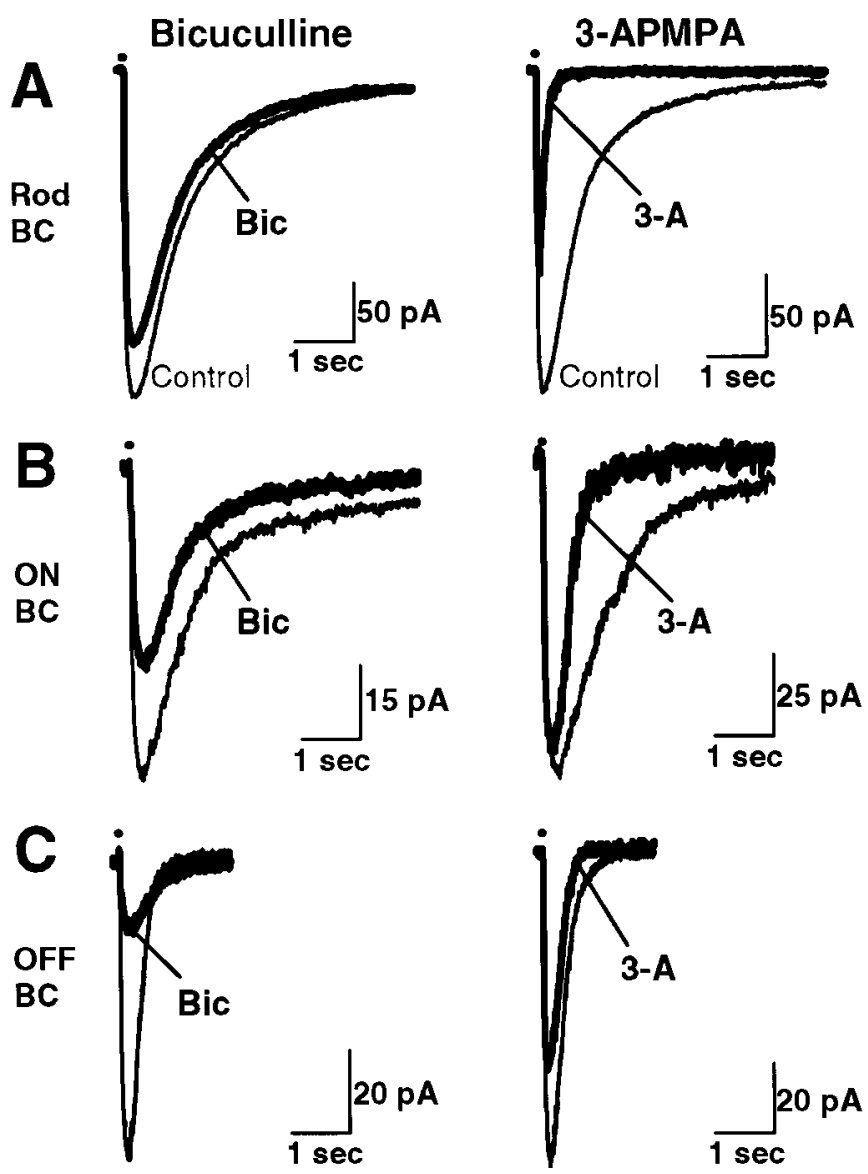

Figure 4. Effects of bicuculline and 3-APMPA on currents evoked in three morphologically distinct bipolar cells. Thin traces (Control in $A$ ) are currents elicited by puffing GABA (200 $\mu \mathrm{M}$ pipette concentration) onto the axon terminals in the absence of GABAergic antagonists. $A-C$, Compared with control levels, bicuculline $(200 \mu \mathrm{M})$ (left column, thick traces, Bic) reduced the charge transfer to $82 \%$ in a $\operatorname{rod}(A), 53 \%$ in an ON cone $(B)$, and $33 \%$ in an OFF cone bipolar cell $(C)$. Relative to control, 3-APMPA $(300 \mu \mathrm{M})$ (right column, thick traces, 3-A) decreased the charge transfer to $11 \%$ in the $\operatorname{rod}(A), 34 \%$ in the ON cone $(B)$, and $57 \%$ in the OFF cone bipolar cell $(C)$. The combination of bicuculline and 3-APMPA abolished responses in each of the three bipolar cells (0-6\% of control levels; data not shown).

\section{GABAergic IPSCs in bipolar cells}

The data reported above confirm that ferret bipolar cell terminals express functional $\mathrm{GABA}_{\mathrm{A}}$ and $\mathrm{GABA}_{\mathrm{C}}$ receptors but do not indicate whether both receptor classes participate in synaptic responses. To determine whether synaptic stimuli activate one or both receptor subtypes, we recorded GABAergic IPSCs evoked by puffing kainate $(500 \mu \mathrm{M})$ in the IPL to depolarize amacrine cell processes. The IPSC depicted in Figure 6 was partially blocked by bicuculline $(200 \mu \mathrm{M})$ and completely abolished with the addition of 3-APMPA $(300 \mu \mathrm{M})$. In six bipolar cells, bicuculline reduced the charge transfer of the IPSC to $29 \pm 12 \%$ of control. 3-APMPA decreased the charge transfer to $8.8 \pm 2.3 \%$ $(n=8)$ of control values. In all cells, the combination of bicuculline and 3-APMPA blocked the response $(1.8 \pm 1.3 \%$ of control $)$, and IPSCs recovered to $62 \pm 5.8 \%$ of control $(n=10)$.

Immunolabeling for $\mathrm{GABA}_{A}$ and $\mathrm{GABA}_{C}$ receptors in the OPL and IPL

Our physiological recordings suggest that responses evoked by puffing GABA in the OPL are dominated by $\mathrm{GABA}_{\mathrm{A}}$ receptors, 
A

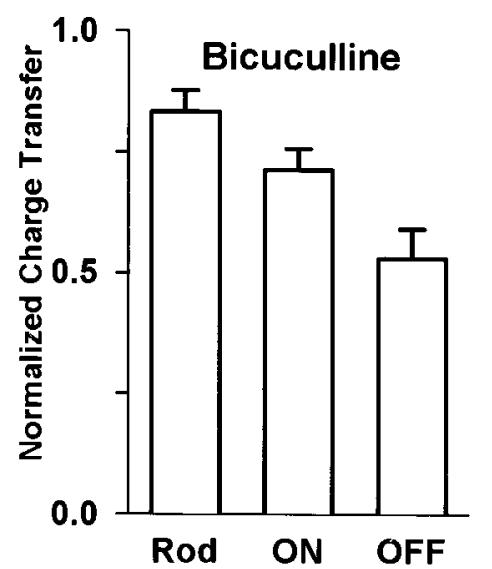

B

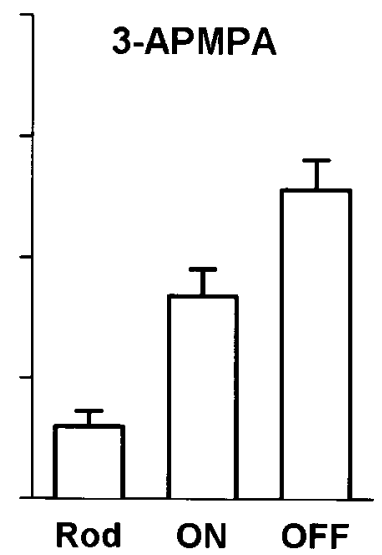

Figure 5. Differential effects of GABAergic antagonists on currents evoked in distinct classes of bipolar cells. A, Effects of bicuculline on the charge transfer of currents evoked by puffing GABA $(200 \mu \mathrm{M}$ pipette concentration) onto the axon terminals. Relative to control, bicuculline $(200 \mu \mathrm{M})$ reduced the charge transfer to $83 \pm 4 \%(n=12)$ in rod $(\operatorname{Rod})$, $71 \pm 4 \%(n=11)$ in ON cone $(O N)$, and $54 \pm 6 \%(n=15)$ in OFF cone $(O F F)$ bipolar cells. The percent blockade by bicuculline was significantly different between rod and ON cone $(p=0.03)$, rod and OFF cone $(p<$ $0.001)$, and ON cone and OFF cone $(p=0.01)$ bipolar cell populations. $B$, Relative to control levels, 3-APMPA $(300 \mu \mathrm{M})$ reduced the charge transfer to $15 \pm 3 \%(n=9)$ in $\operatorname{rod}(\operatorname{Rod}), 37 \pm 6 \%(n=10)$ in ON cone $(O N)$, and $65 \pm 6 \%(n=12)$ in OFF cone $(O F F)$ bipolar cells. The reduction by 3-APMPA was significantly different between populations of rod and ON $(p=0.005)$, rod and OFF $(p<0.001)$, and ON and OFF bipolar cells $(p=0.003)$. In all cells, the combination of bicuculline and 3-APMPA abolished GABA-evoked currents $(2.4 \pm 0.4 \%$ of control levels; $n=50$; data not shown).

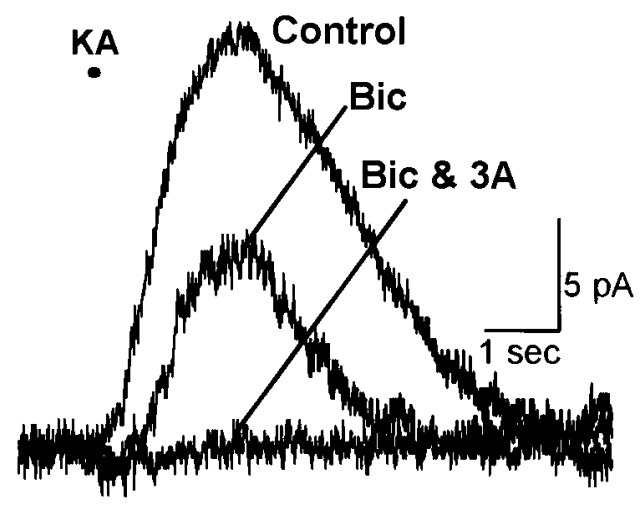

Figure 6. $\mathrm{GABA}_{\mathrm{A}}$ and $\mathrm{GABA}_{\mathrm{C}}$ receptors mediate GABAergic IPSCs. Current responses evoked in an $\mathrm{ON}$ cone bipolar cell by puffing kainate $(500 \mu \mathrm{M})$ in the IPL. Bicuculline $(200 \mu \mathrm{M})$ decreased the response charge transfer to $31 \%(B i c)$, and 3-APMPA $(300 \mu \mathrm{M})$ reduced the bicucullineresistant component to $4 \%$ of control (Bic \& $3 A$ ). Upon washout of antagonist, the IPSC charge transfer recovered to $75 \%$ of control.

whereas responses to puffing in the IPL comprised $\mathrm{GABA}_{\mathrm{A}}$ and $\mathrm{GABA}_{C}$ components. To correlate this finding with the anatomical distribution of these receptor subtypes, we immunolabeled ferret retinal sections for the $\beta 2 / 3$ subunit of the $\mathrm{GABA}_{\mathrm{A}}$ receptor and for the $\rho$ subunit of the $\mathrm{GABA}_{\mathrm{C}}$ receptor (Fig. 7). Immunoreactivity for the $\beta 2 / 3$ subunit (Fig. $7 A$ ) was intense in both the IPL and OPL. In addition, some cell bodies in the inner nuclear layer (INL) and the dendritic processes of these cells also appeared labeled (Fig. 7A). Strong, punctate immunolabeling for

the $\rho$ subunit was also clearly evident in the IPL (Fig. 7B). However, $\rho$ subunit labeling differed from $\beta 2 / 3$ subunit staining in two ways. Unlike $\beta 2 / 3$ subunit labeling, $\rho$ subunit immunoreactivity was strongly concentrated in two bands in the IPL, one band in the proximal (ON) and the other in the distal (OFF) sublamina. In addition, $\rho$ subunit immunoreactivity in the OPL was relatively weak, if at all present (Fig. $7 B$ ). Together, these data suggest that the patterns of immunostaining in the ferret retina were distinct for the $\mathrm{GABA}_{\mathrm{A}}$ and $\mathrm{GABA}_{\mathrm{C}}$ subunits. In addition, the pattern of immunolabeling for $\mathrm{GABA}_{\mathrm{A}}$ and $\mathrm{GABA}_{\mathrm{C}}$ receptor subunits lends support to the physiological findings that GABA-evoked responses in the ferret OPL are mainly mediated by $\mathrm{GABA}_{\mathrm{A}}$ receptors and that responses in the IPL are mediated by both $\mathrm{GABA}_{\mathrm{A}}$ and $\mathrm{GABA}_{\mathrm{C}}$ receptors.

\section{Immunolabeling for $\mathrm{GABA}_{\mathrm{A}}$ and $\mathrm{GABA}_{\mathrm{C}}$ receptors on distinct bipolar cell classes}

Our physiological recordings also suggest that the relative proportions of $\mathrm{GABA}_{\mathrm{A}}$ and $\mathrm{GABA}_{\mathrm{C}}$ receptors on the axons of bipolar cells varied with cell type. In particular, rod bipolar cells appeared to have responses mediated predominantly by $\mathrm{GABA}_{\mathrm{C}}$ receptors, whereas $\mathrm{ON}$ and $\mathrm{OFF}$ cone bipolar cells showed a variety of responses that could reflect differences in receptor complements. To relate the physiological results to the anatomical expression of the two ionotropic GABA receptor subtypes, we compared the patterns of immunolabeling for the $\mathrm{GABA}_{\mathrm{A}}$ receptor $\beta 2 / 3$ subunit and the $\mathrm{GABA}_{\mathrm{C}} \rho$ subunit with immunolabeling for rod and cone (ON and OFF) bipolar cells.

Rod and cone bipolar cells can be distinguished in the ferret retina by immunolabeling for $\mathrm{PKC}$, recoverin, and calbindin (Figs. 8, 9, all shown in green) (Miller et al., 1999). Rod bipolar cells are immunoreactive for PKC, subpopulations of ON and OFF cone bipolar cells label for recoverin, and a subset of ON cone bipolars express calbindin. Figure 8 illustrates the spatial distribution of the axon terminals of ferret rod and cone bipolar cells relative to the distribution of $\mathrm{GABA}_{\mathrm{A}}$ (Fig. 8, blue) and GABA $_{\mathrm{C}}$ subunits (Figs. 8, 9, red). Rod bipolar cells (PKCpositive) had axon terminals that stratified in the inner two-fifths of the IPL in a region that overlaps with the inner band of GABA $_{\mathrm{C}} \rho$ subunit staining (Fig. $8 A$ ). Two major subsets of recoverin-positive bipolar cells could be identified; one population had axon terminals that stratified in the outer IPL, corresponding to the outer $\rho$ subunit band, whereas the terminals of the other population stratified primarily in the sublamina of the IPL that had only weak or sparse $\mathrm{GABA}_{\mathrm{C}}$ staining (Fig. 8C). Calbindinpositive bipolar cells had axon terminals that also stratified primarily in the inner band strongly labeled for $\mathrm{GABA}_{\mathrm{C}}$ receptors (Fig. 8E).

$\mathrm{GABA}_{\mathrm{A}} \beta 2 / 3$ subunit staining showed no unique spatial correspondence to the $\mathrm{PKC}$ - or recoverin-positive terminals (Fig. $8 B, D$ ). The spatial relationship between the location of the axon arbor and the distribution of $\mathrm{GABA}_{\mathrm{A}} \beta 2 / 3$ subunit could not be assessed for calbindin labeling (see Materials and Methods).

To more directly associate the spatial distribution of GABA receptors with the axon terminals of the bipolar cells, we obtained high-magnification 3-D reconstructions of the IPL in the immunolabeled sections. $\mathrm{GABA}_{\mathrm{A}} \beta 2 / 3$ subunit staining was extremely dense and the puncta small compared with $\rho$-subunit staining, rendering it difficult to observe colocalization of this receptor subunit with axonal profiles. We thus focused our analysis on the colocalization of $\rho$ subunit staining with PKC-, recoverin-, and calbindin-labeled axon terminals. We first obtained a short stack 

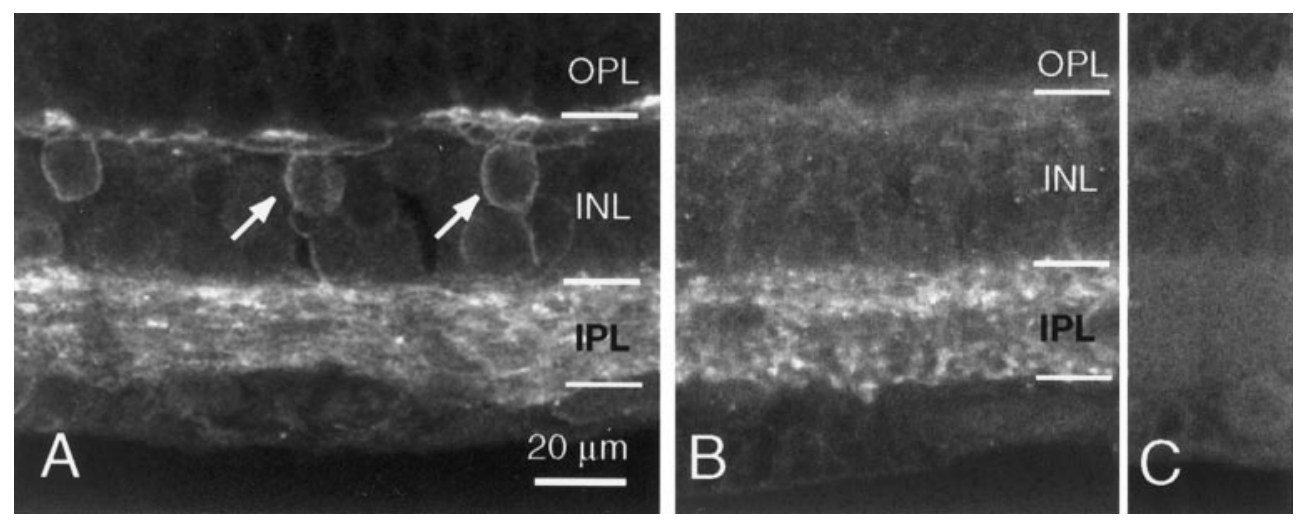

Figure 7. Confocal images of $\mathrm{GABA}_{\mathrm{A}}$ $(A)$ and $\mathrm{GABA}_{\mathrm{C}}(B)$ receptor immunostaining in the adult ferret retina. $A r$ rows in $A$ point to two putative bipolar cells that showed dendritic labeling. $C$, Control section for $\mathrm{GABA}_{\mathrm{C}}$ staining in which the primary antibody was omitted. Images in $B$ and $C$ were acquired with the same objective $(40 \times)$ and at the same laser intensity, gain, and black level.

of confocal images through the region of interest at fine z-steps $(0.1 \mu \mathrm{m})$ and then reconstructed and rotated the images in 3-D. This enabled us to more confidently follow and confirm colocalization of receptor puncta with immunolabeling for the various bipolar cell markers. Only $\rho$ subunit-positive staining or puncta that merged with an axonal profile in all 3-D views were considered to be colocalized with the process. These regions are shaded within an outline of the axon terminals that were reconstructed and represented as a z-projection of the stack in Figure 8, $B, D$, and $F$.

There was clear and qualitatively extensive colocalization of $\rho$ subunit staining with PKC-immunoreactive terminals in the IPL (Fig. 9A,B), supporting the physiological finding that responses evoked by puffing at the axon terminals of these cells are primarily mediated by $\mathrm{GABA}_{\mathrm{C}}$ receptors. Recoverin-positive terminals showed two contrasting patterns of colocalization. Terminals in the outer IPL were heavily colocalized with $\rho$ subunit immunostaining, whereas those in the inner IPL had relatively little GABA $_{C}$ staining (Fig. 9C,D). Thus, some OFF cone bipolar cells with a relatively large $\mathrm{GABA}_{\mathrm{C}}$-mediated component in their physiological response may correspond to recoverin-positive cells with terminals in the distal IPL. Finally, like ON recoverinpositive bipolar cells, the axon terminals of calbindin-labeled bipolar cells also bore little $\mathrm{GABA}_{\mathrm{C}}$ staining, despite their stratification within the inner band of $\mathrm{GABA}_{C}$ expression (Fig. $\left.9 E, F\right)$.

\section{DISCUSSION}

\section{Differential distribution of ionotropic GABA receptors on axons and dendrites}

$\mathrm{GABA}_{\mathrm{A}}$ and $\mathrm{GABA}_{\mathrm{C}}$ receptors differ in their kinetics and affinity for GABA. In this study, we show that these subtypes of GABA receptors have a differential spatial distribution on ferret bipolar cells. Our physiological results demonstrated that bipolar cell dendrites primarily expressed $\mathrm{GABA}_{\mathrm{A}}$ receptors and the axon terminals possessed combinations of $\mathrm{GABA}_{\mathrm{A}}$ and $\mathrm{GABA}_{\mathrm{C}}$ receptors, which varied with bipolar cell type. Consistent with the different functional properties of $\mathrm{GABA}_{\mathrm{A}}$ and $\mathrm{GABA}_{\mathrm{C}}$ receptors, we found that GABA responses at the dendrites and axon terminals were temporally distinct. Our immunocytochemical staining for GABA receptor subunits corroborated our physiological data. Similar to results in other mammalian species, our immunolabeling for $\mathrm{GABA}_{\mathrm{A}}$ and $\mathrm{GABA}_{\mathrm{C}}$ subunits showed a differential spatial distribution in which label for the $\mathrm{GABA}_{\mathrm{A}}$ subunit was intense in the IPL and OPL, and staining for the $\mathrm{GABA}_{\mathrm{C}}$ subunit was strong in the IPL but weak in the OPL. (Greferath et al., 1993, 1994, 1995; Enz et al., 1996; Koulen et al., 1997).

\section{$\mathrm{GABA}_{\mathrm{A}}$ receptors and postsynaptic inhibition}

Postsynaptic inhibition mediated by dendritic $\mathrm{GABA}_{\mathrm{A}}$ receptors is a common feature of most CNS neurons and presumably functions to modulate neuronal responses to excitatory inputs. Our physiological and immunocytochemical data demonstrate that $\mathrm{GABA}_{\mathrm{A}}$ receptors play the major role in mediating dendritic GABA responses in all bipolar cell classes. In contrast, $\mathrm{GABA}_{\mathrm{C}}$ receptors contribute minimally to dendritic responses and exhibit only weak labeling in the OPL. Dendritic $\mathrm{GABA}_{\mathrm{A}}$ receptors most likely receive GABAergic input from interplexiform and horizontal cells (Fisher and Boycott, 1974; Kolb and West, 1977; Chun and Wässle, 1989; Pourcho and Owczarzak, 1989). The function of dendritic GABA receptors in information processing is unknown. A possible role for these GABA receptors would be to modulate the inhibitory surround of bipolar cells, but the results of recent studies in salamander conflict with this possibility (Hare and Owen, 1996; Cook and McReynolds, 1998). Although the precise function of GABA receptors on bipolar cell dendrites is unclear, they likely function in regulating responses to glutamatergic input, similar to other dendritic $\mathrm{GABA}_{\mathrm{A}}$ receptors in the CNS.

\section{Relative roles of $\mathrm{GABA}_{\mathrm{A}}$ and $\mathrm{GABA}_{C}$ receptors in presynaptic inhibition}

In the CNS, the activation of ionotropic receptors on the axon terminal can modulate the release of neurotransmitters (for review, see MacDermott et al., 1999). Glutamate release from the axon terminals of salamander retinal bipolar cells is most likely modulated by two types of ionotropic GABA receptors (Lukasiewicz and Werblin, 1994; Dong and Werblin, 1998). These two receptor subtypes can be simultaneously activated by GABA puffed onto the terminals or by GABA released from presynaptic amacrine cells. Both our time course and pharmacological data reveal two components in the GABA-evoked response, indicating that both $\mathrm{GABA}_{\mathrm{A}}$ and $\mathrm{GABA}_{\mathrm{C}}$ receptors mediate these currents in ferret bipolar cell terminals. These observations are corroborated by our immunocytochemical staining for $\mathrm{GABA}_{\mathrm{A}}$ and $\mathrm{GABA}_{\mathrm{C}}$ receptor subunits.

Why are two ionotropic receptors for GABA necessary to modulate glutamate release from the bipolar terminals? Because of the distinct affinities and kinetics of the $\mathrm{GABA}_{\mathrm{A}}$ and $\mathrm{GABA}_{\mathrm{C}}$ receptors, a combination of these receptors on a single axon terminal offers a much larger dynamic range in the summed response to GABA than the expression of either subtype alone. For example, compared with $\mathrm{GABA}_{\mathrm{A}}, \mathrm{GABA}_{\mathrm{C}}$ receptors can respond to much lower concentrations of GABA. Furthermore, 

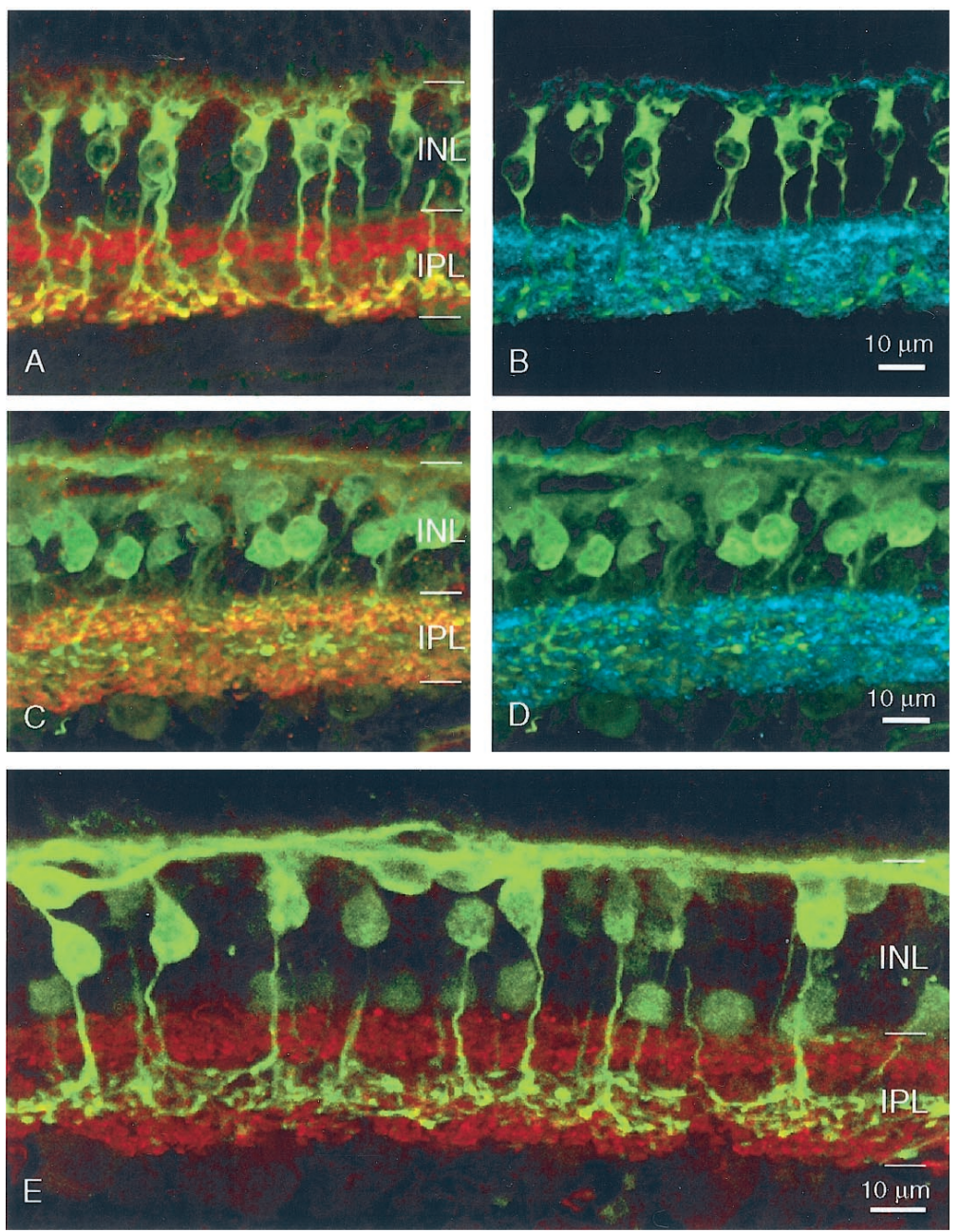

INL
Figure 8. Top. Confocal images (each panel represents the maximum intensity projection of a stack of $10-15$ images) demonstrating patterns of immunostaining for bipolar cells, $\mathrm{GABA}_{\mathrm{A}}$, and $\mathrm{GABA}_{\mathrm{C}}$ receptors in the adult ferret retina. $\mathrm{GABA}_{C}$ receptor immunolabeling is encoded in red, whereas $\mathrm{GABA}_{\mathrm{A}}$ receptors are in shown in blue. PKC $(A, B)$, recoverin $(C, D)$, and calbindin $(E)$ immunolabeling for bipolar cells are shown in green. Figure 9. Bottom. High magnification of the maximum intensity projections of short z-stacks of 10-15 images of the IPL showing colabeling of $\mathrm{GABA}_{C}$ receptors $(\mathrm{red})$ with bipolar cell axon terminals (green). Bipolar cell terminals were labeled for PKC $(A)$, recoverin $(C)$, and calbindin $(E)$. Silhouettes of the labeled bipolar terminals in $A, C$, and $E$ are shown in $B, D$, and $F$, respectively. Colocalization with $\mathrm{GABA}_{C}$ staining is represented by the red profiles, determined after 3-D rotation of the image stacks.
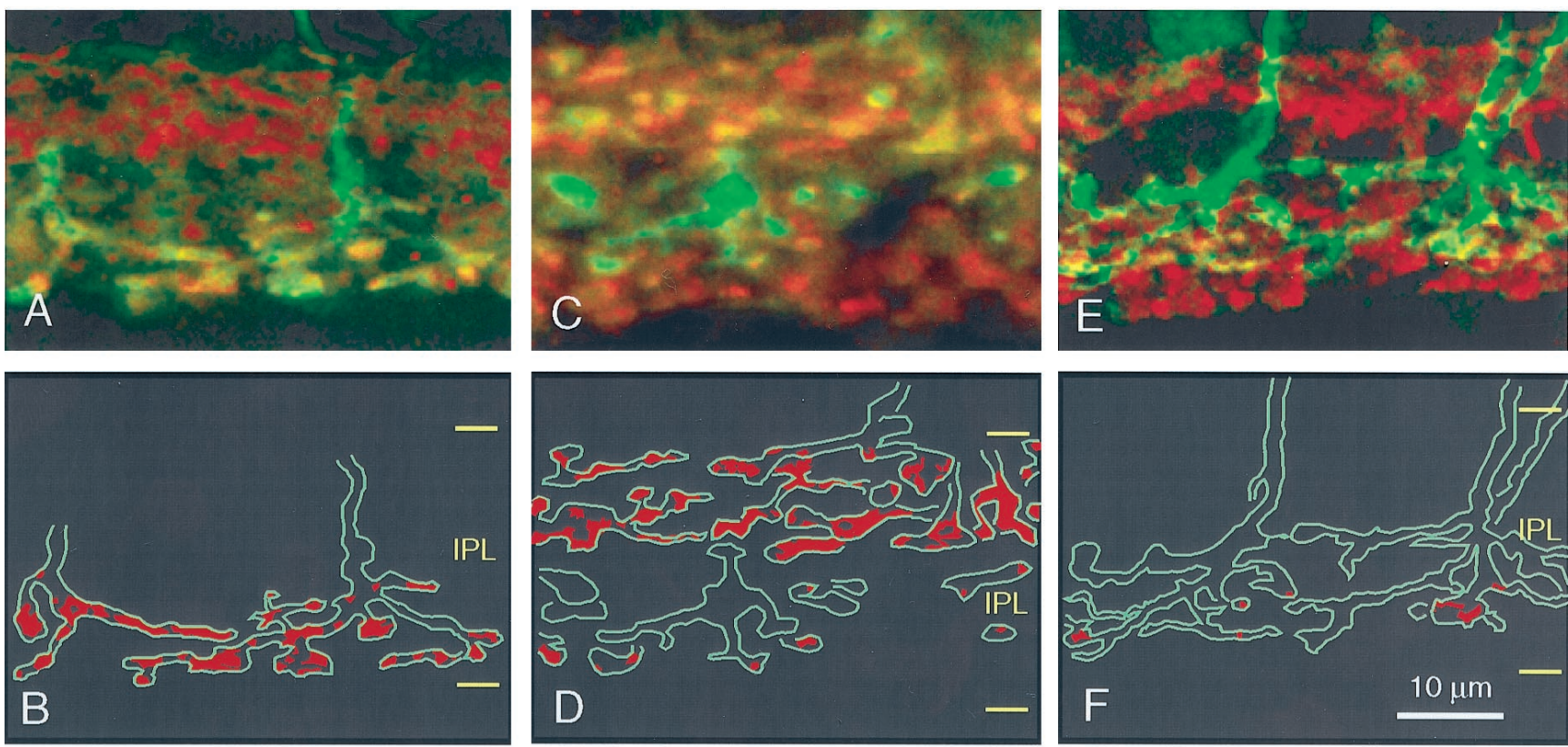
activation of $\mathrm{GABA}_{\mathrm{C}}$ receptors yields a more sustained inhibition relative to that provided by $\mathrm{GABA}_{\mathrm{A}}$ receptors. Because the release of glutamate from bipolar cells can be relatively slow and sustained compared with that from a spiking neuron, $\mathrm{GABA}_{\mathrm{C}}$ receptors can provide inhibition that is temporally matched to the kinetics of this release. In contrast, $\mathrm{GABA}_{\mathrm{A}}$ receptors, which mediate fast responses to GABA, offer the ability to rapidly and transiently suppress glutamate release. The idea that the temporal characteristics of inhibitory currents shape the timing of the suppression of bipolar cell activity was examined by Pan and Lipton (Pan and Lipton, 1995). They demonstrated that inhibitory currents mediated by $\mathrm{GABA}_{\mathrm{A}}$ receptors rapidly and transiently suppressed depolarization-induced $\mathrm{Ca}^{2+}$ currents in dissociated rat bipolar cells. In contrast, $\mathrm{GABA}_{\mathrm{C}}$ receptor-mediated suppression of the $\mathrm{Ca}^{2+}$ current was slower in onset and more sustained. Furthermore, Dong and Werblin (1998) showed that $\mathrm{GABA}_{\mathrm{C}}$ (and not $\mathrm{GABA}_{\mathrm{A}}$ ) receptors are responsible for the inhibition of maintained glutamate release from bipolar cells, which may underlie the generation of transient excitation in ganglion cells (Dong and Werblin, 1998).

Immunocytochemical staining suggests that $\mathrm{GABA}_{\mathrm{A}}$ and $\mathrm{GABA}_{\mathrm{C}}$ receptor subunits do not colocalize at the same synaptic sites (Koulen et al., 1998). Apart from the distinct properties of $\mathrm{GABA}_{\mathrm{A}}$ and $\mathrm{GABA}_{\mathrm{C}}$ receptors, differences in the spatial location of these receptor subtypes relative to synaptic sites may also contribute to the regulation of release from bipolar terminals. One possibility is that low-affinity $\mathrm{GABA}_{\mathrm{A}}$ receptors are located at GABAergic synapses, whereas higher-affinity $\mathrm{GABA}_{\mathrm{C}}$ receptors are distributed extrasynaptically in which they could respond to GABA spillover into extrasynaptic space. This arrangement exists in the rat cerebellum in which high-affinity extrasynaptic $\mathrm{GABA}_{\mathrm{A}}$ receptors with $\delta$ subunits mediate a sustained response, and lower-affinity synaptic $\mathrm{GABA}_{\mathrm{A}}$ receptors without $\delta$ subunits mediate transient responses (Nusser et al., 1998). Recent ultrastructural evidence, however, suggests that $\mathrm{GABA}_{\mathrm{C}}$ receptors cluster at synaptic sites in rat retina (Koulen et al., 1998). Furthermore, our study demonstrated that both $\mathrm{GABA}_{\mathrm{A}}$ and $\mathrm{GABA}_{\mathrm{C}}$ receptors mediate GABAergic IPSCs. These findings suggest that $\mathrm{GABA}_{\mathrm{C}}$ receptors can be activated synaptically but do not exclude the possibility of activation by spillover of GABA from distant release sites. If $\mathrm{GABA}_{\mathrm{A}}$ and $\mathrm{GABA}_{\mathrm{C}}$ receptors are located at distinct synapses, perhaps each receives input from different types of GABAergic amacrine cells. Such an arrangement has been observed in the hippocampus in which two kinetically distinct $\mathrm{GABA}_{\mathrm{A}}$ synaptic responses are mediated by different inhibitory circuits (Banks et al., 1998).

\section{Differences in the relative expression of $\mathrm{GABA}_{A}$ and $\mathrm{GABA}_{C}$ receptors on distinct classes of bipolar cells}

Results of experiments in both ferret and rat indicate that the $\mathrm{GABA}_{\mathrm{A}}$ to $\mathrm{GABA}_{\mathrm{C}}$ receptor ratio varied among different morphological classes of bipolar cells (Euler and Wässle, 1998). In our experiments, focal puffs of GABA onto either the dendritic or axonal arbors of ferret bipolar cells evoked responses that showed differences in the $\mathrm{GABA}_{\mathrm{A}}$ to $\mathrm{GABA}_{\mathrm{C}}$ receptor ratio specifically for currents elicited at the axon terminals. In the rat, responses were evoked by bath application of GABA, which presumably activated dendritic as well as axonal GABA receptors (Euler and Wässle, 1998). These responses showed differences in the $\mathrm{GABA}_{\mathrm{A}}$ to $\mathrm{GABA}_{\mathrm{C}}$ receptor ratio for currents mediated simultaneously by dendritic and axonal GABA receptors. Thus, differ- ences in GABA application methodologies may explain any discrepancies between these two studies.

In both ferret and rat (Euler and Wässle, 1998), rod bipolar cells clearly possess the highest $\mathrm{GABA}_{\mathrm{C}}$ to $\mathrm{GABA}_{\mathrm{A}}$ ratio. This high ratio is confirmed by immunocytochemical localization of $\mathrm{GABA}_{\mathrm{C}}$ receptor staining to $\mathrm{PKC}$-positive bipolar cells in retinae of the ferret and other species (Enz et al., 1996; Koulen et al., 1997). Our population data also suggest a general trend for the component of the response mediated by $\mathrm{GABA}_{\mathrm{C}}$ receptors to increase from OFF cone to ON cone to rod bipolar cells. However, there are some exceptions to this trend within ON and OFF cone populations. For example, a subpopulation of OFF bipolar cells showed a relatively large $\mathrm{GABA}_{\mathrm{C}}$ component compared with other OFF bipolar cells. From our immunocytochemical staining for $\mathrm{GABA}_{\mathrm{C}}$ receptors, this population may correspond to that which is immunopositive for recoverin. In contrast, some ON bipolar cells appear to have a small $\mathrm{GABA}_{\mathrm{C}}$ component. These cells may be the calbindin- and recoverin-positive $\mathrm{ON}$ bipolar cells identified in our immunocytochemistry.

Why do distinct classes of bipolar cells express different ratios of $\mathrm{GABA}_{\mathrm{C}}$ to $\mathrm{GABA}_{\mathrm{A}}$ receptors on their axon terminals? One possibility is to match the temporal characteristics of excitatory and inhibitory responses. The kinetic properties of responses in the rod and cone pathways are distinct. Rod light responses are 10 times slower than cone responses, and the kinetics of synaptic transfer are 10 times longer at rod synapses than at cone synapses (Schnapf and Copenhagen, 1982). Noise analysis indicates that cone-mediated synaptic events in $\mathrm{ON}$ bipolar cells were longer than those in OFF bipolar cells (Ashmore and Copenhagen, 1980), consistent with the notion of slower synaptic transfer in the ON cone pathway compared with the OFF cone pathway. These differences are most likely attributable to the presence of metabotropic glutamate receptors on ON bipolar cell dendrites (Slaughter and Miller, 1981; Nawy and Jahr, 1990) and kainate receptors on OFF bipolar cell dendrites (Devries and Schwartz, 1999). Our results show that the kinetics of inhibition at the bipolar cell terminals is matched to the kinetics of the excitatory responses in different classes of bipolar cells. Rod bipolar cells have the slowest excitatory responses and the largest complement of $\mathrm{GABA}_{\mathrm{C}}$ receptors, whereas OFF cone bipolar cells have the fastest excitatory responses and generally possess the largest complement of $\mathrm{GABA}_{\mathrm{A}}$ receptors. This arrangement may ensure that inhibitory currents are sustained enough to prevent rebound excitation, yet brief enough to permit responses to subsequent stimuli.

\section{REFERENCES}

Ames A, Nesbett FB (1981) In vitro retina as an experimental model of the central nervous system. J Neurochem 37:867-877.

Amin J, Weiss DS (1994) Homomeric $\rho 1$ GABA channels: activation properties and domains. Receptors Channels 2:227-236.

Ashmore JF, Copenhagen DR (1980) Different postsynaptic events in two types of retinal bipolar cell. Nature 288:84-86.

Banks MI, Li T-B, Pearce RA (1998) The synaptic basis of GABA $A_{\text {,slow }}$. J Neurosci 18:1305-1317.

Belgum JH, Dvorak DR, McReynolds JS (1984) Strychnine blocks transient but not sustained inhibition in mudpuppy retinal ganglion cells. J Physiol (Lond) 354:273-286.

Bormann J, Feigenspan A (1995) GABA $_{C}$ receptors. Trends Neurosci 18:515-519.

Chun M, Wässle H (1989) GABA-like immunoreactivity in the cat retina: electron microscopy. J Comp Neurol 279:55-67.

Cook PB, McReynolds JS (1998) Lateral inhibition in the inner retina is important for spatial tuning of ganglion cells. Nat Neurosci 1:714-719.

Devries SH, Schwartz EA (1999) Kainate receptors mediate synaptic 
transmission between cones and OFF bipolar cells in a mammalian retina. Nature 397:157-160.

Dong C, Werblin FS (1998) Temporal contrast enhancement via GABA feedback at bipolar terminals in the tiger salamander retina. J Neurophysiol 79:2171-2180.

Enz R, Brandstätter JH, Wässle H, Bormann J (1996) Immunocytochemical localization of the $\mathrm{GABA}_{\mathrm{C}}$ receptor $\rho$ subunits in the mammalian retina. J Neurosci 16:4479-4490.

Euler T, Wässle H (1995) Immunocytochemical identification of cone bipolar cells in the rat retina. J Comp Neurol 361:461-478.

Euler T, Wässle $\mathrm{H}$ (1998) Different contributions of $\mathrm{GABA}_{\mathrm{A}}$ and $\mathrm{GABA}_{\mathrm{C}}$ receptors to rod and cone bipolar cells in a rat retinal slice preparation. J Neurophysiol 79:1384-1395.

Famiglietti Jr EV, Kolb H (1976) Structural basis for ON- and OFFcenter responses in retinal ganglion cells. Science 194:193-195.

Feigenspan A, Bormann J (1994) Differential pharmacology of GABA and $\mathrm{GABA}_{\mathrm{C}}$ receptors on rat retinal bipolar cells. Eur J Pharmacol 288:97-104.

Feigenspan A, Wässle H, Bormann J (1993) Pharmacology of GABA receptor $\mathrm{Cl}^{-}$channels in rat retinal bipolar cells. Nature 361:159-162.

Fisher SK, Boycott BB (1974) Synaptic connexions made by horizontal cells within the outer plexiform layer of the retina of the cat and the rabbit. Proc R Soc Lond B Biol Sci 186:317-331.

Greferath U, Müller F, Wässle H, Shivers B, Seeburg P (1993) Localization of $\mathrm{GABA}_{\mathrm{A}}$ receptors in the rat retina. Vis Neurosci 10:551-561.

Greferath U, Grünert U, Müller F, Wässle H (1994) Localization of $\mathrm{GABA}_{\mathrm{A}}$ receptors in the rabbit retina. Cell Tissue Res 276:295-307.

Greferath U, Grünert U, Fritschy JM, Stephenson A, Mohler H, Wässle $\mathrm{H}$ (1995) $\mathrm{GABA}_{\mathrm{A}}$ receptor subunits have differential distributions in the rat retina: in situ hybridization and immunohistochemistry. J Comp Neurol 353:553-571.

Hamill OP, Marty A, Neher E, Sakmann B, Sigworth FJ (1981) Improved patch clamp techniques for high resolution current recording from cells and cell-free patches. Pflügers Arch 391:85-100.

Hare WA, Owen G (1996) Receptive field of the retinal bipolar cell: a pharmacological study in the tiger salamander. J Neurophysiol 76:2005-2019.

Hevers W, Lüddens H (1998) The diversity of GABA $_{A}$ receptors: pharmacological and electrophysiological properties of $\mathrm{GABA}_{\mathrm{A}}$ channel subtypes. Mol Neurobiol 18:35-86.

Kolb H, West RW (1977) Synaptic connections of the interplexiform cell in the retina of the cat. J Neurocytol 6:155-170.

Koulen P, Brandstätter JH, Kroger S, Enz R, Bormann J, Wässle H (1997) Immunocytochemical localization of the $\mathrm{GABA}_{\mathrm{C}}$ receptor $\rho$ subunits in the cat, goldfish and chicken retina. J Comp Neurol 380:520-532.

Koulen P, Brandstätter JH, Enz R, Bormann J, Wässle H (1998) Synaptic clustering of $\mathrm{GABA}_{\mathrm{C}}$ receptor $\rho$-subunits in rat retina. Eur J Neurosci 10:115-127.

Lukasiewicz PD (1996) GABA $_{C}$ receptors in the vertebrate retina. Mol Neurobiol 12:211-224.

Lukasiewicz PD, Roeder RC (1995) Evidence for glycine modulation of excitatory synaptic inputs to retinal ganglion cells. J Neurosci 15: 4592-4601.
Lukasiewicz P, Shields C (1998a) Different combinations of $\mathrm{GABA}_{\mathrm{A}}$ and $\mathrm{GABA}_{\mathrm{C}}$ receptors confer distinct temporal properties to retinal synaptic responses. J Neurophysiol 79:3157-3167.

Lukasiewicz PD, Shields CR (1998b) A diversity of GABA receptors in the retina. Semin Cell Dev Biol 9:293-299.

Lukasiewicz P, Werblin F (1988) A slowly inactivating potassium current truncates spike activity in ganglion cells of the tiger salamander retina. J Neurosci 8:4470-4481.

Lukasiewicz PD, Werblin FS (1994) A novel GABA receptor modulates synaptic transmission from bipolar to ganglion and amacrine cells in the tiger salamander retina. J Neurosci 14:1213-1223.

Lukasiewicz PD, Wong ROL (1997) GABA $_{C}$ receptors on ferret retinal bipolar cells; a diversity of subtypes in mammals? Vis Neurosci 14: 989-994.

MacDermott AB, Role LW, Sieglbaum SA (1999) Presynaptic ionotropic receptors and the control of transmitter release. Annu Rev Neurosci 22:443-485.

Miller ED, Tran MN, Wong GK, Oakley DM, Wong ROL (1999) Morphological differentiation of bipolar cells in the ferret retina. Vis Neurosci 16:1133-1144.

Mittman S, Taylor WR, Copenhagen DR (1990) Concomitant activation of two types of glutamate receptor mediates excitation of salamander retinal ganglion cells. J Physiol (Lond) 428:175-197.

Nawy S, Jahr CE (1990) Suppression by glutamate of cGMP-activated conductance in retinal bipolar cells. Nature 346:269-271.

Nelson R, Famiglietti Jr EV, Kolb H (1978) Intracellular staining reveals different levels of stratification for On- and Off-center ganglion cells in cat retina. J Neurophysiol 41:472-483.

Nusser Z, Sieghart W, Somogyi P (1998) Segregation of different $\mathrm{GABA}_{\mathrm{A}}$ receptors to synaptic and extrasynaptic membranes of cerebellar granule cells. J Neurosci 18:1693-1703.

Pan Z-H, Lipton SA (1995) Multiple GABA receptor subtypes mediate inhibition of calcium influx at rat retinal bipolar cell terminals. J Neurosci 15:2668-2679.

Peichl L, Wässle H (1981) Morphological identification of On- and Offcentre brisk transient (Y) cells in the cat retina. Proc R Soc Lond B Biol Sci 212:139-156.

Pourcho R, Owczarzak M (1989) Distribution of GABA immunoreactivity in the cat retina: a light- and electron-microscopic study. Vis Neurosci 2:425-435.

Qian H, Dowling JE (1993) Novel GABA responses from rod-driven retinal horizontal cells. Nature 361:162-164.

Qian H, Dowling JE (1995) $\mathrm{GABA}_{\mathrm{A}}$ and $\mathrm{GABA}_{\mathrm{C}}$ receptors on hybrid bass retinal bipolar cells. J Neurophysiol 74:1920-1928.

Schnapf JL, Copenhagen DR (1982) Differences in the kinetics of rod and cone synaptic transmission. Nature 296:862-864.

Slaughter MM, Miller RF (1981) 2-Amino-4-phosphonobutyric acid: a new pharmacological tool for retina research. Science 211:182-185.

Woodward RM, Polenzani L, Miledi R (1993) Characterization of bicuculline/baclofen-insensitive ( $\rho$-like) gamma-aminobutyric acid receptors expressed in Xenopus oocytes. II. Pharmacology agonists and antagonists. Mol Pharmacol 43:609-625. 